\title{
Unburied Practices of Memory: The Holocaust and the Polish-Jewish Relations in Joanna Rudniańska's Kotka Brygidy (2007) and XY (2012)
}

\author{
Mateusz Świetlicki ${ }^{1}$ (i) $\cdot$ Dorota Michułka² ${ }^{2}$
}

Accepted: 24 December 2021

(c) The Author(s) 2022

\begin{abstract}
In many Polish children's books published in the last twenty years the relationship between Jews and Poles during the Holocaust is presented as an unburied theme which can be interpreted in the context of both collective and private/individual cultures of remembrance. Therefore, in this case, we deal with experiences confirmed in the cultural and written order rather than existentially faced. In contemporary Poland, a practically monoethnic and predominantly Catholic country, where the largest number of Jews killed by the Nazis lived before World War II, there is a syndrome of silence concerning the Holocaust. This paper focuses on analysing Joanna Rudniańska's Kotka Brygidy [Brygida's Cat] (2007) and XY (2012), two unique works in the genre of Polish Holocaust children's fiction which combine parable, magic realism, and postmodern fairy tale. The authors argue that Rudniańska's texts belong not only to the group of literary works known as children's literature of atrocity or the literature of genocide for young people but also literature of testimony
\end{abstract}

\footnotetext{
Mateusz Świetlicki is an Assistant Professor at the University of Wrocław's Institute of English Studies. He is a founding member of the Centre for Research on Children's and Young Adult Literature (Faculty of Letters, University of Wrocław). He is a Fulbright, Kościuszko, Harvard University, and Internationale Jugendbibliothek fellow. Świetlicki's research interests include children's and YA literature and culture, memory studies, gender studies, popular culture, and film. He is currently working on a book project on memory in Ukrainian Canadian children's historical fiction. He is a representative for the Childhood \& Youth Network of the SSHA and and a member of the consortium of The International Master in Children's Literature, Media and Culture (University of Glasgow).
}

\begin{abstract}
Dorota Michułka is Head of the University of Wrocław's Department of Polish Language and Literature Teaching Methodology. She is a Polish philologist and historian specialising in the history of literature, Polish language teaching, literature for children, literary and cultural education (also from the historical perspective), school reception of literature and culture, and humanities education from socio-cultural perspectives. In 2000-2005 she worked as a Polish language teacher in Finland (Slaavilainen filologian laitos, Tampereen yliopisto, Suomi), where she also taught Polish literature and culture. She was a visiting scholar in the Netherlands (Department of Social Science Leiden) and the USA (University of Minnesota, Minneapolis, College of Education and Human Development). She is the editor-in-chief of "Filoteknos" (ERIH+).
\end{abstract}

Extended author information available on the last page of the article 
with its authenticity and referentiality as an element of figural realism. Analysing Rudniańska's works, they show how she, the daughter of a Holocaust survivor who did not want to talk about the traumatic war experience, not only writes about the unburied themes but also crosses genre boundaries by mixing realistic figures with stories firmly rooted in a poetic, metaphorical, and magic atmosphere with subjective and expressive narration.

Keywords Memory · Unburied themes · Children's literature · WWII · Holocaust · Poland $\cdot$ Jews $\cdot$ Polish-Jewish relations

The Holocaust, and the cultural trauma associated with it, is an important theme in contemporary children's literature both in Europe (cf. Bosmajian, 2002; Shavit, 2005; Wójcik-Dudek, 2016) and North America (cf. Kokkola, 2003; Świetlicki, 2020; Crocket, 2020). While historical books for young readers often feature oversimplifications and generalisations, children's literature about the Shoah “can be conceived as having a greater moral obligation to be historically accurate than historical fiction dealing with less catastrophic events" (Kokkola, 2003, p. 3). As Adrienne Kertzer, the daughter of a Holocaust survivor, contends, "children, and not just survivors' children, can handle stories about the Holocaust" (2002, p. 26). The question is what children can take out of such stories.

The Holocaust raises questions about the dynamics between memory and truth. After all, every testimony is partial, and therefore, incomplete. In books about the Shoah, there is an unresolved testimony of trauma and an attempt to fill in the missing pieces. Textual memory, the memory of witnesses, becomes an impulse to create existential works, deeply rooted in axiological contexts (Young, 1998, p. 670). The questions addressed in this type of children's fiction concern the relation between the Holocaust and the lives of present-day young people, descendants of the survivors and bearers of postmemory (Hirsch, 1992, 1997), or ones who may include the Shoah in their mnemonic repertoires through the contact with places of memory, like museums, or cultural texts. ${ }^{1}$ Moreover, as Eric Tribunella notes in his examination of American literature, children's books frequently refer to traumatic events "as a way of provoking or ensuring the development of children" (2010, p. xi). By breaking the silence and challenging unburied themes, various authors of children's

\footnotetext{
1 Alison Landsberg analyses the role of popular culture in the transfer of memories which she calls prosthetic, "derived from engagement with mediated representation (seeing a film, visiting a museum, watching a television miniseries)" which are "sensuous memories produced by an experience of massmediated representations" (2004, p. 20, emphasis in original). Anastasia Ulanowicz uses the term second-generation memory, which "involves an individual's conscious recognition of the ways in which her present circumstances have been mediated and shaped by past events that she herself did not directly experience” (2013, p. 4). Mateusz Świetlicki, “[a]dapting Ulanowicz's notion of second-generation memory" uses "a slightly different, yet more precise, term-next-generation memory, which better reflects the potential of the transfer of memory, both described in children's books, where the givers of memories are often elderly family members, representatives of the third and fourth generations, as well as the one that can potentially occur between young readers and mnemonic narratives" (2020, p. 88).
} 
literature attempt to create narratives relevant to young readers who are increasingly looking for answers to the often distressing present-day reality. We use the word unburied in the understanding proposed by Alexander Etkind in Warped Mourning Stories of the Undead in the Land of the Unburied (2013). Writing about post-Soviet Russia, Etkind argues that repressed, controversial historical matters remain unburied and "return as the undead" in cultural texts (2013, p. 18). As Etkind notes, "[e] mbracing the confusion of present and past, the obsessive reenactment of the loss, and the disturbed and disjointed nature of the relationship to the present, the melancholic dialectic of reenactment and defamiliarization produces a rich but puzzling imagery" (p. 19).

In several Polish children's books published in the twenty-first century, the relationship between Jews and Poles is presented as an unburied theme that can be interpreted in the context of collective and individual culture of remembrance. It can be both a mediated experience and a specific cultural artifact. Therefore, in this case, we are dealing with experiences confirmed in the cultural and written order, rather than existentially faced. In contemporary Poland, a practically monoethnic and predominantly Catholic country, where a significant number of Jews killed by the Nazis lived before World War II, there is a syndrome of silence concerning the Holocaust (Tych, 2009, pp. 40-53). As Michael C. Steinlauf argues in Bondage to the Dead: Poland and the Memory of the Holocaust (1997), after the end of World War II the Holocaust discourse was Polonised by the Communist state with the use of school education. The focus of the national narrative was put on highlighting the suffering of the Polish nation and presenting it as equal to that of the Jews. Hence, in this narrative, Poles emerge as Hitler's main victims who were either murdered by the Nazis or risked lives by hiding Jews (cf. Radziwiłł, 1989; Trojański, 1998). In history textbooks published between 1949 and 1989 the Holocaust was shown as just one aspect of Hitler's policies in occupied Poland and the extermination of Jews was marginalised (cf. Radziwiłł, 1989). Changes introduced in textbooks published after the collapse of Communism were gradual-in the 1990s only a few of them included detailed information about the proportion of Jews and Poles killed in concentration camps (Tych, 1998, p. 36; cf. Ubertowska, 2007).

As Barbara Törnquist-Plewa notes, "the picture of the Holocaust transmitted in Polish schools from 1949 to the late 1990s was grossly distorted" and characterised by "omissions" and "false information" (2012, p. 15). This, as she argues, helps to comprehend the disbelief most Poles felt after the publication of Jan Gross' provocative book Sasiedzi (Neighbors, 2000). The consequent "Jedwabne affair" and the debates about anti-Semitism "became the catalyst for a broad discussion, albeit led by intellectuals, about Polish national identity, its contents and its future" (2012, p. 24). Małgorzata Wójcik-Dudek observes that young Poles' memory about the Holocaust is still largely shaped by school education (2020, p. 311). As she contends, Polish schools struggle with addressing the Holocaust because it "was isolated from the thematic range of Jewish history and culture" and became the "centre of school narratives about Jews" (p. 311). Consequently, she points to the "weak representation 
of the Jewish-related literature" and the fetishization of "the Holocaust" (p. 311). ${ }^{2}$ What is particularly appalling about it is the continuing lack of knowledge about the complex Polish-Jewish relations in a country with rising rates of anti-Semitism and ultra-nationalism. Despite the initial difficulties in de-Polonising the Holocaust, dozens of popular literary works for young readers about it have been published over the last twenty years, including novels and picturebooks, memoirs, recollections, autobiographies, and biographies, such as Irena Landau's Ostatnie piętro (2015) illustrated by Joanna Rusinek, Dorota Combrzyńska-Nogala's Bezsenność Jutki (2012), Roma Ligocka's Dziewczynka w czerwonym płaszczyku (2001), Joanna Papuzińska's Asiunia (2013), or Cezary Harasimowicz's Mirabelka (2018) (cf. Wójcik-Dudek, 2020; Michułka, Świtała, Gregorowicz, 2021). Polish children and young adults can also read translations of Anglophone books, often with narratives set in fantastic realities, talking about World War II indirectly with the use of poetic, allegorical, and metaphorical language, like Han Nolan's If I Should Die Before I Wake (1994), Jane Yolen's Briar Rose (1992) and The Devil's Arithmetic (1988), or Yann Martel's Beatrice and Virgil (2010).

In this paper, we focus on analysing Joanna Rudniańska's Kotka Brygidy [Brygida's Cat] (2007), named one of the best books of the year by the Polish section of IBBY, and XY (2012; illustrated by Jacek Ambrożewski), two of the most important and critically-acclaimed works in the category of Polish Holocaust children's fiction. We argue that Rudniańska's portrayal of Polish-Jewish relations is multi-layered and both books uniquely combine elements of realism, fairy tale, magic realism, and postmodern fairy tale (Kostecka, 2014, p. 9). Examining Kotka Brygidy and $X Y$, we read them as books belonging not only to the group of literary works known as children's literature of atrocity (Kidd, 2005, p. 121) or the literature of genocide for young people (Gangi, 2014, p. 7), but also literature of testimony with its authenticity and referentiality as an element of figural realism. Hayden White follows the example of Erich Auerbach and his theory of mimesis and, on the basis of testimonies of the Holocaust described by Primo Levi, writes that " $[\mathrm{t}]$ he most vivid scenes of the horrors of life in the camps produced by Levi consist less of the delineation of 'facts' as conventionally conceived than of the sequences of figures he creates by which to endow the facts with passion, his own feelings about and the value he therefore attaches to them" (White, 2004, p. 119). The phenomenon of figural realism is also linked to the concept of ekphrasis-mutual relations, a kind of transfer of literary expression to the world of art-rich in mental, poetic images, and metaphors. Analysing Rudniańska's works we show how she, the daughter of a Holocaust survivor who did not want to talk about the traumatic war experience (Wójcik-Dudek, 2016, p. 165), not only writes about the unburied themes, most importantly the question of Polish-Jewish identity, but also crosses genre boundaries by mixing realistic figures with stories firmly rooted in a poetic, metaphorical, and magic atmosphere with subjective and expressive narration.

\footnotetext{
${ }^{2}$ It is worth noting that there are some exceptions in the Polish school literary canon, for examples the works of Ida Fink (cf. Michułka, Świtała, Gregorowicz, 2021) and Andrzej Szczypiorski (cf. Bortkowski, 1993). In Poczatek (The Beautiful Mrs. Seidenman, 1987) Szczypiorski "broke with the myth of benevolent and sacrificial Poles" by writing about "the different attitudes of his compatriots towards Jews ... and trying to answer the eternal question: what is Polishness?" (Bortkowski, 1993, p. 64).
} 


\section{Kotka Brygidy}

The protagonist of Kotka Brygidy, a novel for children 13+, is a six-year-old Polish girl named Helena. The story takes place in Warsaw, and the action begins in the summer of 1939 and continues through World War II, with the epilogue happening in present-day reality. Helena is a happy child with loving, open-minded parents. Helena's mother teaches her that "there is one God" (Rudniańska, 2007, p. 13) and some of her best friends are Jewish. Stańcia, the nanny, an older woman who seems bizarre and irresponsible, is the only member of Helena's household who openly displays any signs of anti-Semitism. Helena's pre-war life seems idyllic and the single thing she misses is a sibling or a pet. Hence she is delighted after finding a stray, magical cat which is wise and can talk. Helena's parents do not want her to keep it, though. Kamil, a young Jewish man who works at the production plant run by Helena's father, decides to save the cat and gives it to his younger sister, Brygida. The cat brings elements of magical realism to the novel, as it understands more than people, has a strong intergenerational memory, comments on the course of events, explains some situations, reveals the truths, and finally, in a magical way, saves Brygida by taking her out of the ghetto. Remarkably, while Helena is the protagonist, it is Brygida who gets to own the cat and it is her name which appears in the title of the novel. This seems to symbolically highlight Helena's status as a bystander (cf. Hilberg, 1992). While she gets to tell the story, just like the cat, it is Brygida's story. As Wójcik-Dudek argues, after the war the memories of Brygida and the Holocaust continue haunting Helena, who seems to be "possessed by a Dybbuk of memory" (2016, p. 283). In the epilogue, Helena dies and miraculously turns into a cat, a descendant of the eponymous cat who possesses the memory of its ancestors, and leaves present-day Warsaw to travel to Jerusalem to finally reunite with Brygida. Consequently, after decades of thinking about it, Helena becomes Brygida's cat.

Helena's life before the outbreak of WWII seems perfect because her father, a resourceful and enterprising man, manages his company reliably and fairly, taking care of his employees and maintaining friendly relations with the inhabitants of his tenement house, mostly Jews. Knowledge of the German language allows Helena's father to successfully do business with Germans. The outbreak of WWII and the anti-Semitic witch-hunts do not break the old friendships. Consequently, when friends of the family are closed in the ghetto, Helena's parents rush to their aid. They let Kamil hide in their plant. The effort to help the Jews continues throughout the war and is not limited to acquaintances.

The story is told consistently from the perspective of a bystander observer, it is often objective rather than personal, and uses free indirect discourse (cf. Leskiv, 2009). The narrator can also cleverly look into the mind of the protagonist. Helena ponders on what motivates some actions of the adults; she asks honest, direct questions, and has a natural curiosity about the world. Helena understands a lot, as can be seen in the following passage: "it's interesting what it's like in that cellar, where Kamil lived. How can one stay all the time in the cellar? And what was Kamil doing there all day long?" (Rudniańska, 2007, p. 108). She knows not to tell anyone about the fact that Kamil is hiding but cannot stop thinking about him. Because Helena 
is an observer and a witness, her perspective is that of an outsider. The obligation to testify is passed on to the youngest generation along with the desire to preserve the strength of objective observation; for example, in the scene when Helena rides a tram through the ghetto with her father who asks her to remember, the intergenerational transmission of memory is emphasised. This scene makes Helena's father even a more multi-layered character. When Helena naively asks him "maybe we are Jews too?" he replies "You are right, Helena. We are Jews. Now every decent man is a Jew" (Rudniańska, 2007, p. 115). While it is suggested that he may be helping the Jews not solely gratuitously but also for profit, he wants to make sure that his daughter does not forget about their fate. Forcing Helena to look through the tram's window, he risks traumatizing her, yet knows that it is the only way to make her remember about the Warsaw Ghetto.

The theme of the Holocaust is presented in Kotka Brygidy primarily in the context of the notion of space, heterotopia, to use Michel Foucault's concept. Behind the Warsaw Ghetto borders, ghastly normality takes place, a peculiar ritual of everyday ghetto life, with the running theme of survival and the great escape. Heterotopia, a phenomenon from the field of humanistic geography, horizontally intersects emplacements with placeless places and overlaps other spaces. As such, it refers directly to the concept of mirror reflections, literary alternative worlds, and simultaneous and parallel realities. We can see its presence in such literary genres as utopia and dystopia, or in literary conventions based on magical realism in the area of speculative literature, including fantasy and science-fiction. Spaces in Rudniańska's works, which cross genre boundaries and combine historical fiction with magical realism, are also heterotopic. Heterotopia, like utopia, will often be an unreal image, a specific reflection of social life. As Walter Russell Mead writes, "Utopia is a place where everything is good; dystopia is a place where everything is bad; heterotopia is where things are different- that is, a collection whose members have few or no intelligible connections with one another" (1995, online). Interestingly, a similar literary device was also used in other Polish Holocaust books, Pamiętnik Blumki (2011) by Iwona Chmielewska or Ostatnie przedstawienie panny Esterki (2013; first published in German as Fräulein Esthers letzte Vorstellung: Eine Geschichte aus dem Warschauer Ghetto) by Adam Jaromir and Gabriela Cichowska (cf. Bieber, 2015).

Helena visits the ghetto with her father, witnessing death and mortal danger. She intuitively senses the degree of risk and rejects the symptoms of anti-Semitism displayed by Poles, including her nanny Stańcia and neighbour Mrs Szewczykowa. Helena recounts the tragedy in a childish way: naively but faithfully, not omitting drastic details. Another interesting aspect of the novel is that the narrator shows that the images of atrocities can mingle in wartime reality with the joy of a child's everyday play. Rudniańska maintains a reflective distance to the described developments by using a literary trick of presenting wartime events and extermination of Jews from the perspective of a child who is not a Jew but a Pole, and who "is not affected by mass extermination of Jews directly but is its close witness" (Mizuro, online). Her initial gullibility can be observed when she sees a man being chased by Nazi soldiers and does not understand that they want to hurt him. While "the man jumped forward and fell to the pavement" and after the attack "a red trickle was running from the head of the lying man," Helena "got up slowly as if nothing 
happened and started skipping through the rope again, jumping in the direction of her home, she saw briefly the young soldier grinning at her, at the little jumping girl" (Rudniańska, 2007, p. 30). The juxtaposition of play and atrocity in this scene is striking. Throughout the novel Helena grows up and gradually gets used to the wartime reality; she also stops being surprised by everything. Therefore, the narrative freely transitions to impassive "non-fiction" literature, for instance in the scene when Helena observes the march of Jews from the Praga district to the ghetto on the other side of the Vistula River and sees it as something normal. The epilogue shows that this memory continued haunting Helena long after the end of the war. She never married and, unlike other Poles, she never Polonised her memory of the Holocaust; she also kept on thinking about Brygida, displaying a strong need to help stray cats and remind people of the fate of Warsaw Jews.

The seemingly naïve perspective can also be seen in the scene where Helena receives an armband with the Star of David as a gift from Tomek, her Jewish friend. The boy jokingly tells her that the armband is a magical item that reveals things invisible to others. Tomek gives this special gift to Helena on the condition that she will agree to their future marriage. Helena gladly accepts it as an attractive piece of clothing and says laconically that it matches her coat. However, after deciding to put it on, she notices that it is, indeed, a special gift, provoking negative reactions of adults—people who were usually friendly do not even look at her and either pretend that she is invisible or openly show her hostility. For the first time Helena appears to be more than a passive bystander as she starts to understand that the armband is not just an item of clothing. In this scene, Helena for a moment symbolically becomes Jewish. After performing Jewishness and experiencing prejudice expressed by previously friendly people, like Mr Gienio and Mrs Szewczykowa, Helena begins to understand what is happening to the Jews.

The relationship between Poles, Jews and the unburied practices of memory also refer to the level of axiology and not directly named emotions. The narrative of those fairy-tale parables is characterised by silence and lack of adjectives. In Kotka Brygidy the ubiquitous fear of death and the trauma of war are "hidden" behind a veil of good and kind attitudes towards people afflicted by evil. Helena is, above all, a witness to the "quiet heroism" of many Poles saving Jews. According to Marta Mizuro, "a child's perspective adopted by the author primarily serves to make the heroism seem ordinary, show it as a natural act of kindness and adherence to one's convictions" (Mizuro, online). Helena's parents are in this regard no exception as they help a number of Jews. It is not only Kamil but also several unfamiliar people and family friends. Róża, a close friend of Helena's mother, also stays there for some time. She has to pretend to be a maid by "walk[ing] with her hair tied back and w[earing] an apron" (Rudniańska, 2007, p. 107). Helena is told that Róża, who "had documents of one Polish woman who had already died," does "not look at all like a Jew" (Rudniańska, 2007, p. 107). While at first the girl does not understand what it means to look like a Jew, she observes their "visitors" changing their appearance, for example "a young lady" who "bleached her hair, rested, and changed into one of mum's pretty dresses” (Rudniańska, 2007, p. 78). Rudniańska breaks a cultural taboo by suggesting that Helena's father may be helping the Jews mostly for money. While this aspect of the novel was criticised by Anna Maria Krajewska (2008, pp. 
47-49), as Krzysztof Rybak notes (2018, p. 177), it was surprisingly disregarded by Wójcik-Dudek in her close analysis of the novel. Though the acts of saving Jews by hiding them and forging "Aryan papers" were always dangerous as by helping Jews Poles risked execution, there were cases of doing it for profit (Snyder, 2015, p. 275). Still, this controversial aspect of the Polish-Jewish relations remains unburied. While Helena seems too young to fully comprehend the nature of her father's actions, in the epilogue she tells Brygida that she suspects her father's acts were not selfless. The possibility of her father having a mercenary interest haunts adult Helena, especially since he decided to conceal his involvement in rescuing Jews. Because after the war he did not want anyone to know he hid Kamil, Helena does not get to meet Brygida sooner. Helena's father's attitude is not surprising, though. After all, as Timothy Snyder observes, in Communist Poland "[ $\mathrm{t}]$ hose who saved Jews were portrayed as those who somehow got more money for saving them than they did by killing them" (Snyder, 2015, p. 275). In the epilogue Brygida tells Helena that her father's intentions do not matter-what does matter is that he did help to save several Jews.

A significant role in the novel is played by the motif of time used as an excuse to juxtapose the period of war with the present day; the "inhabitants"/protagonists living in the latter period do not know, or no longer remember, any wartime nightmares and the fate of the Jewish population of pre-war Warsaw. The representation of time and space in Kotka Brygidy can also take on the role of chronotope as defined by Mihail Bakhtin, who claims that "time, as it were, thickens, takes on flesh, becomes artistically visible; likewise, space becomes charged and responsive to the movements of time, plot and history. This intersection of axes and fusion of indicators characterizes the artistic Chronotope" (Bakhtin, 1981, p. 85). Consequently, we are dealing here with a clear overlapping of a narrative based on historical truth with fiction enhanced by memory of the past, which is pointed out by, among others, Kokkola in her discussion of the chronotope of the Holocaust based on Sue Vice's considerations (2003, p. 68). Vice points to three levels of the literary realization of chronotope: "first as the means by which a text represents history; second, as the relation between images of time and space in the novel, out of which any representation of history must be reconstructed; and third, as a way of discussing the formal properties of the text itself, its plot, narrator, and relation to other texts" (qtd in Kokkola, 2003, p. 68). As Kokkola notes, "the first two have the most relevance" (Kokkola, 2003, p. 68). The second level is especially interesting in the context of Kotka Brygidy. After the war Helena decides to live in the former Warsaw Ghetto. For years she observes people who, unlike the eponymous cat, do not possess their ancestors' memories and seem to be ignorant towards the past. While for them Nowolipki is a regular Warsaw neighbourhood, Helena constantly reconstructs its WWII image. Thinking about Brygida, she does not know that the woman lives on the other side of the wall-in a building connected to Helena's, yet one formally located in a different street. Only when Brygida decides to leave Poland for Israel do the women briefly meet. Because Brygida does not know Helena and is not familiar with the fact that the protagonist's family hid Kamil, she believes that Helena is crazy. The woman has to die and become a cat to be reunited with Brygida, who used to be the girl Helena wanted to save and befriend in childhood. 
Kotka Brygidy also fits into the category of Holocaust children's books depicting the perspective of child survivors. As Vice notes, such narratives contain "[s] ections about the traumatic past [which] alternate with sections describing the present" (2004, p. 12). Moreover, "[s]uch texts are also divided between a child's and an adult's perspective; the past of the Holocaust is the time of childhood, its effects that of adulthood" (Vice, 2004, p. 12). The categories of time and space become more specific when Brygida and Helena appear as adult survivors. The storyline continues as a chain of differing memories, which are woven into the epilogue taking place in present-day Warsaw and then briefly in Jerusalem. While Brygida and Helena talk about the same past, referring to the same people and events, their recollections significantly differ.

The perspective of an adult looking back at the times of war in Children's literature complicates the image of the reality during the occupation. Combining elements of biographical fiction with an autobiographical narrative allows authors to include confessions, testimonies, and reflections (cf. Lejeune, 1975). Adult Helena and Brygida see before their eyes images of memories like impressionist paintings-blurry spots as isolated moments and emotion-laden scenes, which at times function as conceptual metaphors. They include places, people, the smell of coffee, and the taste of cigarettes - mental images in the style of poetic prose are filtered through experiences and emotions, which "flow through the city like shreds of mist, enticing... eyes with faded colours" (Rudniańska, 2007, p. 153).

Consequently, an important aspect of these considerations is the strategy of representation of the Holocaust-historical representation and the category of historical experience associated more with the concept of historical interpretations of events rather than an objective record of the experience. Therefore, the postmodern fairy tale, due to the child audience, suspended somewhere between fantasy and parable, and elements of magical realism, with features of figural realism, allow the use of the concept of a meta-narrative and meta-history as used by Hayden White (1975) and his follower Frank Ankersmit (2001). Using the perspective of a child bystander and adopting the convention of magical realism in Holocaust literature may be considered problematic as such books can potentially lead to the evasion of challenging historical issues. In Kotka Brygidy Rudniańska does not avoid complex matters, on the contrary, she successfully incorporates the unburied theme of Polish-Jewish relations during World War II which she further explores in $X Y$.

\section{$X Y$}

A similar, yet more radical, narrative climate of a postmodern fairy tale with elements of a parable but taking place in a specific setting can be found in Rudniańska's 2012 picturebook $X Y$ illustrated by Jacek Ambrożewski (Wójcik-Dudek, 2016, p. 159). Unlike Kotka Brygidy, $X Y$ was written for younger children aged 8-11. While the narrative choice of a postmodern fairy tale may seem surprising in the context of the Holocaust, traditional fairy tales help children tame their fears and anxieties. Fairy tales, similarly to illustrated books and picturebooks, are usually told/read to children by/with adults. After all, as Maria Nikolajeva notes, "[c]hildren have limited 
life experience of emotions; therefore, fiction can offer vicarious emotional experience that children can partake of in a safe mode" (2011, p. 121). Moreover, books combining text and illustrations can potentially make readers interested in "the time-space of a particular period because of the opportunities for visually displaying points of reference between the past and the present moment" (Kokkola, 2003, p. 69). Ambrożewski's postmodern illustrations certainly make $X Y$ a more complex and non-linear narrative, yet they can also help draw young readers' attention to the story. All pictures are predominantly black, white, and grey-the only other colour appearing in $X Y$ is green, symbolising hope and new life. While Wójcik-Dudek calls the illustrations kamishibai-style (Wójcik-Dudek, 2016, p. 159), it is worth noting that some of them look like playful children's doodles and handprints.

$X Y$ is a fairy tale and a picturebook about separated Jewish twin sisters born in unusual circumstances in the forest and later raised in different families-one as a Pole and the other as a Jew. The beginning of the story is set in the Polish countryside in the Bug River area in 1932. At that time many residents of Warsaw spent holidays in the east of Poland. The girls are raised in Warsaw but eventually find shelter in the pastoral space of eastern Poland. The character of a peculiar old woman, whose portrayal combines elements of reality and transcendence, binds the whole story together. The woman lives alone on the edge of the forest; her appearance seems realistic, and she resembles a folk herbalist: she is short and stooped, wears scarves and skirts, but her extraordinary "clear, amethyst and unforgettable" (Rudniańska and Ambrożewski, 2012, p. 9) eyes point to the realm of a fairy tale. The woman shapeshifts throughout the story-she is either old or young and elegant. Only her amethyst eyes remain the same.

A mythical element is also the category of time, as seen, among others, in the significant, recurring moments of the story, or the precise, designated scene when the children are handed over to their new families. The meeting with the new mothers is to take place "on the fourth day, at the right time" (Rudniańska and Ambrożewski, 2012, p. 12). On that day, at the "right" time, the girls are separated and go to two different families. Both of them are rather wealthy, yet the one given to the Jewish family is believed to be luckier. Both girls are given the same name-Hanna. While the name, meaning "favour" and "grace," is common among Poles and Jews, in the context of the story it shows the fairy tale strength of blood ties. As we learn from the epilogue, the characters were inspired by Rudniańska's mother, also named Hanna (diminutive Hania). The narrator distinguishes between the twins by calling them Hania X and Hania Y, symbolically pointing to the fact that the girls are mirror reflections of one another. When the war breaks out, Hania $\mathrm{X}$ has to move with her parents to the ghetto, and Hania Y's parents try to hide the girl's Jewish heritage. Eventually the sisters are reunited and survive the war by pretending to be a single person-a Polish girl.

Despite the magical elements found in the text and portrayed in the illustrations, $X Y$ does not turn into a typical fairy tale. The narrative becomes more similar to other Holocaust-themed texts filled with depictions of death, loss, and hunger (Wójcik-Dudek, 2016, p. 160). The story emphasizes the realistic, historical message, and includes a clear context of wartime reality. There are scenes of bombardment, the occupation of Warsaw, the listing of Jews, marking of Jews with the Star 
of David armband, and images of the ghetto. The lives of the two girls go on independently but they can both "feel" their mental closeness after seeing each other from a distance in the ghetto. Rudniańska uses a similar motif as in Kotka BrygidyHania Y takes the Warsaw Ghetto tram, sees her sister, and cannot stop thinking about her. In $X Y$ Rudniańska explores the unburied theme of identity-the protagonists are Jewish, but one of them is raised Polish, and later both of them successfully perform Polishness. In Kotka Brygidy Kamil, like other neighbours and family friends of Helena, "became a Jew because of the war" (Rudniańska, 2007, p. 34). Even after moving to Jerusalem Brygida feels most comfortable using Polish. In $X Y$ Rudniańska addresses the issues of being Polish and Jewish at the same time.

After all, the internal dilemmas of Hania Y circle around finding her identity; she is engaged in a dialogue with herself, asking significant questions about her-and her sister's-place in the world: "That girl was in the ghetto, a prison town surrounded by a high wall. The ghetto was inhabited by the Jews, which means that the girl was a Jew. And maybe I am a Jew, too? Perhaps this will be revealed soon, and I will have to stay in that terrible place?" (Rudniańska and Ambrożewski, 2012, p. 23). While she is not sure of her heritage, she "bent her head low so that no one would notice she was a Jew" (Rudniańska and Ambrożewski, 2012, p. 23). Interestingly, after seeing Hania $\mathrm{X}$ in the ghetto, she does not consider the possibly of both of them not being Jewish.

The maturation of the protagonists is determined by their search for identity in wartime reality and the ethical dilemmas associated with finding physical indicators of Polishness and Jewishness. A significant moment of the story is the scene when Hania $\mathrm{X}$ is looking at herself in the mirror trying to find signs of Jewishness: "[s]he stood in front of the mirror and carefully examined her face. Her hair was neither dark nor fair but auburn; her eyes were a bit green like bottles and a bit dark like puddles in the street. Who am I? she thought" (Rudniańska and Ambrożewski, 2012 , p. 30). She also thinks about her biological and adoptive mothers: "Who was the woman that gave birth to me? Was she a Jew? And why did she leave me in the forest? Or maybe she was a gypsy? And why, Hania X asked herself, was everyone telling me that I look so similar to my mum while my mum is not, in fact, my real mum!" (Rudniańska and Ambrożewski, 2012, p. 30). Her questions remain unanswered but may potentially lead to an intergenerational dialogue between the child and adult readers. Eventually Hania X manages to escape the ghetto in disguise and is miraculously saved thanks to the intervention of magical powers. During her escape from the ghetto, she comes across a carriage carrying an elegant woman in a lilac hat who turns out to be the magical old lady. She takes Hania X to the family home of her sister-Hania Y (Rudniańska and Ambrożewski, 2012, p. 36). As in Kotka Brygidy, only magical powers can help escape from the ghetto. Unfortunately, Hania X's adoptive family is not guided by supernatural powers, and they are all killed.

The issue of Polish rescuers of Jews is also explored in $X Y$. When the twins start living together they cannot reveal it as it would put them at risk. The turmoil of war lingers, and the anti-Semitic witch-hunts continue. Therefore, the girls make up "a play of non-existence" where one of them stays hidden: "No one will know there are two of us,' said Hania Y. 'We will pretend to be one. It won't be difficult,' 
agreed Hania X” (Rudniańska and Ambrożewski, 2012, p. 45). Rudniańska shows that Hania Y's parents are not willing to take the risk of rescuing a Jewish girl at first. The girls, who are identical, do not want to tell the parents which one is which. Hence the parents agree to follow Hanias' hazardous plan and eventually end up loving both girls. When one of their neighbours notices that there are two girls in the family and tries to denounce Hanias' parents, he is stopped, possibly killed, by the magical powers guiding the girls. Although the identity of the girls is eventually determined and they are reunited, the play of non-existence becomes, in fact, a fight for survival, ending in a superficial victory. The triumph is illusory. Unlike in a typical fairy tale, the ending in $X Y$ is not unequivocally happy. Ambrożewski's illustrations symbolise its apparent nature. The first double-spread depicts eighteen black tree-like handprints with roots and green leaves. The last double-spread features a similar image, yet one of the handprints is crossed out this time. Moreover, none of them have roots and look more like fragments of a demolished wall. No leaves are growing out of the hands. Instead, the fingerprints seem to be bleeding. Hania $\mathrm{X}$ loses her entire family and has to pretend to be her sister who was raised Polish and Catholic. After the war she cannot return to her former life. Hania X is helpless and displays typical symptoms of trauma - she keeps on crying at night and looks for comfort in her dog Cygan (Gypsy), who miraculously rejoins her at the end of the book and is the only material proof of her past. Rudniańska's $X Y$ shows that while often fairy tales can help children process fear and anxiety, conventional patterns cannot be naively used in the context of the Holocaust. Magical powers save Hanias, but they cannot save all Warsaw Jews. Hence in her magical realist novel and fairy tale picturebook Rudniańska explores the limitations which traditional narrative formats display when challenged with the Shoah (cf. Wójcik-Dudek, 2016, pp. 165-166).

\section{Conclusion}

There are two main aspects of the Holocaust discourse: the need for a confirmation and the inability to confirm (Kaniewska, 2009). In this case, the division into experienced history and confirmed history proposed by Jerzy Jedlicki loses validity (1978). Rudniańska's stories encourage discussions on the role of history and memory in the education of young generations and reflect the sense of the findings described by Pierre Nora, who claims that memory and history are not only synonymous anymore but appear as fundamentally contradictory concepts. Memory refers to a life led by living societies established in their name. Continually evolving, it is open to the dialectic of remembering and forgetting, oblivious to its gradual deformation, prone to manipulation and appropriation, it may continue in dormancy and occasionally wake up. On the other hand, history is always a problematic and incomplete reconstruction of what no longer exists (Nora, 1989).

Rudniańska's critically-acclaimed Kotka Brygidy and XY depict the Polish-Jewish dialogue as a mixture of interpersonal relationships (among family and friends) and a representation of important intergenerational dialogues and ethical attitudes. Hence we may argue that they have the potential to become a significant educational 
tool in lessons about the complex Polish-Jewish past. Both stories discuss duality and involve depictions of mirror reflections and mirrored spaces. They also tackle identity problems-mainly the question of being Jewish and Polish. In the epilogue of Kotka Brygidy we learn that for years Helena and Brygida were neighbours but did not know about it. They are eventually reunited by the cat—Brygida has had to give it away as she is finally moving to Israel. In Jerusalem Brygida does not belong, she goes to the hairdresser every week only because she wants to speak Polish. Helena, on the other hand, desperately tries to preserve the memory of the Holocaust and the Warsaw Ghetto but eventually dies alone and misunderstood. Hania $\mathrm{X}$ and Hania $\mathrm{Y}$ are reunited, but their experiences and memories differ. After all, only one of them suffered a double loss-of her Jewish family and Jewish identity.

Kotka Brygidy and $X Y$ acknowledge cultural trauma but also reveal unburied themes. On the one hand, they constitute a model of transition from a "selectively hidden" world to a reality which is "read aloud" and discussed. Kotka Brygidy and $X Y$ also allow for an accumulation of the symbolic capital needed to carry out possible changes of perception of the past. On the other hand, both books demonstrate that next-generation memory is like a palimpsest with clear, realistic figures and metaphors, which refers to the concept of a still unfinished (hence unburied) and complex dialogue between Poles and Jews, as well as the question of identity.

Open Access This article is licensed under a Creative Commons Attribution 4.0 International License, which permits use, sharing, adaptation, distribution and reproduction in any medium or format, as long as you give appropriate credit to the original author(s) and the source, provide a link to the Creative Commons licence, and indicate if changes were made. The images or other third party material in this article are included in the article's Creative Commons licence, unless indicated otherwise in a credit line to the material. If material is not included in the article's Creative Commons licence and your intended use is not permitted by statutory regulation or exceeds the permitted use, you will need to obtain permission directly from the copyright holder. To view a copy of this licence, visit http://creativecommons.org/licen ses/by/4.0/.

\section{References}

Ankersmit, Frank. (2001). Historical Representation. Stanford: Stanford University Press.

Bakhtin, Mihail. (1981). The Dialogic Imagination: Four Essays. translated by Caryl Emerson and Michael Holquist. Austin: University of Texas Press.

Bieber, Ada. (2015). Mentoring in an Heterotopic Space-Janusz Korczak's Orphanage in Contemporary Picture Books. Filoteknos, 5, 181-189.

Bortkowski, Stanisław. (1993). Głosy do „Początku” Andrzeja Szczypiorskiego. In Alicja Krawczyk (Ed.), Tematyka żydowska $w$ lekturach szkolnych licealistów (pp. 61-64). Kielce: Wydawnictwo Pedagogiczne ZNP.

Bosmajian, Hamida. (2002). Sparing the Child: Grief and the Unspeakable in Youth Literature about Nazism and the Holocaust. New York-London: Routledge.

Crocket, Talia E. (2020). The Silence of Fragmentation Ethical Representations of Trauma in Young Adult Holocaust Literature. Barnboken, 43, https://doi.org/10.14811/clr.v43i0.487

Etkind, Alexander. (2013). Warped Mourning Stories of the Undead in the Land of the Unburied. Stanford: Stanford University Press.

Gangi, Jane M. (2014). Genocide in Contemporary Children's and Young Adult Literature: Cambodia to Darfur. Routledge. 
Hilberg, Raul. (1992). Perpetrators, Victims, Bystanders: The Jewish Catastrophe, 1933-1945. New York: Aaron Asher Books.

Hirsch, Marianne (1992). Family Pictures: Maus, Mourning, and Post-Memory. Discourse, 15(2), 3-29.

Hirsch, Marianne. (1997). Family Frames: Photography, Narrative, and Postmemory. Cambridge: Harvard UP.

Jedlicki, Jerzy. (1978). Dzieje doświadczone i dzieje zaświadczone. In Zofia Stefanowska and Janusz Sławiński (Eds.), Dzieło literackie jako źródto historyczne (pp. 344-371). Warszawa: Czytelnik.

Kaniewska, Barbara. (2009). Literackie kształty inicjacji. Powieść o dojrzewaniu wobec doświadczenia Zagłady. In Przemysław Czapliński and Ewa Domańska (Eds.), Zagłada. Współczesne problemy rozumienia i przedstawiania (pp. 183-193). Poznań: Poznańskie Studia Polonistyczne.

Kertzer, Adrienne. (2002). My Mother's Voice: Children, Literature, and the Holocaust. Peterborough: Broadview Press.

Kidd, Kenneth B. (2005). A" is for Auschwitz: Psychoanalysis, Trauma Theory, and the "Children's Literature of Atrocity. Children's Literature, 33, 120-149.

Kokkola, Lydia. (2003). Representing Holocaust in Children's Literature. New York-London: Routledge.

Kostecka, Weronika. (2014). Baśń postmodernistyczna: przeobrażenia gatunku. Warszawa: Wydawnictwo SBP.

Krajewska, Anna Maria. (2008). Przestrzeń nadziei. Debiuty po 1990 roku. In Danuta ŚwierczyńskaJelonek, Grzegorz Leszczyński, Michał Zając (Eds.), Po potopie. Dziecko, ksiażka i biblioteka w XXI wieku (pp. 47-49). Warszawa: Wydawnictwo SBP.

Landsberg, Alison. (2004). Prosthetic Memory: The Transformation of American Remembrance in the Age of Mass Culture. New York: Columbia University Press.

Lejeune, Philippe. (1975). Le Pacte autobiographique. Paris: Le Seuil.

Leskiv, Alina (2009). The Literary Phenomenon of Free Indirect Speech. Studia Anglica Resoviensia, $6(60), 51-58$.

Mead, Walter Russell. (1995). Trains, Planes, and Automobiles: The End of the Postmodern Moment. World Policy Journal, 12 (4). Accessed December 23, 2020 from http://link.galegroup.com/apps/ doc/A17886037/EAIM?u=glasuni\&sid=EAIM\&xid=37f58ab9

Mizuro, Marta. (n.d.). Kotka Brygidy. Instytut Książki. Accessed December 23, 2020 from http://www. instytutksiazki.pl/ksiazki-detal,literatura-polska,2556,kotka-brygidy.html

Michułka, Dorota, Świtała, Sabina, and Gregorowicz, Łukasz (2021). Czytanie pamięci : cisza, czas i emocje w opowiadaniach Idy Fink. Slavica Wratislaviensia, 173, 303-331.

Nikolajeva, Maria. (2011). "The Penguin Looked Sad" Picturebooks, Empathy and Theory of Mind. In Bettina Kümmerling-Meibauer (Ed.), Picturebooks: Representation and Narration (pp. 121-138.). New York-London: Routledge.

Nora, Pierre. (1989). Between Memory and History: Les Lieux de Mémoire. Trans. Marc Roudebush. Representations 26, (Spring), 7-24.

Radziwiłł, Anna (1989). The Teaching of the History of the Jews in Secondary Schools in the Polish People's Republic, 1949-88. Polin, 4, 402-424.

Rudniańska, Joanna. (2007). Kotka Brygidy. Warszawa: Pierwsze.

Rudniańska, Joanna and Jacek Ambrożewski. (2012). XY. Warszawa: Muchomor.

Rybak, Krzysztof (2018). Sparing Them the Trauma: Postmemory Practices in Contemporary Polish Children's Literature about the Holocaust. Filoteknos, 8, 169-183.

Shavit, Zohar. (2005). A Past Without Shadow: Constructing the Past in German Books for Children. New York-London: Routledge.

Snyder, Timothy. (2015). Black Earth: The Holocaust as History and Warning. New York: Tim Duggan Book 2015.

Steinlauf, Michael C. (1997). Bondage to the Dead: Poland and the Memory of the Holocaust. New York: Syracuse University Press.

Świetlicki, Mateusz. (2020). 'You will bear witness for us': Suppressed Memory and Counterhistory in Marsha Forchuk Skrypuch's Hope's War (2001).'Anglica Wratislaviensia, LVIII, 83-95.

Törnquist-Plewa, Barbara (2012). The Use and Non-Use of the Holocaust Memory in Poland. In Barbara Törnquist-Plewa and Niklas Bernsand (Eds.), In Painful Pasts and Useful Memories Remembering and Forgetting in Europe, (pp. 11-28). Lund: Lund University.

Tribunella, Eric L. (2010). Melancholia and Maturation: The Use of Trauma in American Children's Literature. Knoxville: University of Tennessee Press.

Trojański, Piotr. (1998). Nazizm i Holokaust w edukacji historycznej młodzieży szkoły podstawowej. In Pro Memoria, Biluletyn Informacyjny Muzeum Oświęcim-Brzezinka. 
Tych, Feliks. (1998). Problem Holokaustu w polskich podręcznikach szkolnych. Biuletyn Żydowskiego Instytutu Historycznego, 4 (188).

Tych, Feliks. (2009). Potoczna świadomość Holokaustu w Polsce - jej stan i postulaty edukacyjne. In Przemysław Czapliński and Ewa Domańska (Eds.), Zagłada. Wspótczesne problemy rozumienia $i$ przedstawiania (pp. 40-53). Poznań: Poznańskie Studia Polonistyczne.

Ubertowska, Aleksandra. (2007). Świadectwo - trauma - głos. Literackie reprezentacje Holokaustu. Kraków: Universitas.

Ulanowicz, Anastasia. (2013). Second Generation Memory and Contemporary Children's Literature. Ghost Image. New York-London: Routledge.

Vice, Sue. (2004). Children Writing the Holocaust. Basingstoke: Palgrave.

White, Hayden. (1975). Metahistory. The Historical Imagination in Nineteenth-Century Europe. Baltimore and London: Johns Hopkins University.

White, Hayden (2004). Figural Realism in Witness Literature. Parallax, 10(1), 113-124.

Wójcik-Dudek, Małgorzata. (2016). W(y)czytać Zagładę. Praktyki postpamięci w polskiej literaturze XXI wieku dla dzieci i młodzieży. Katowice: Wydawnictwo Uniwersytetu Śląskiego.

Wójcik-Dudek, Ma.łgorzata (2020). Memory Boom and Imaginarium of Holocaust in Polish Literature for Young Readers. Filoteknos, 10, 309-323.

Young, James E. (1998). The Holocaust as Vicarious Past: Art Spiegelman "Maus" and the Afterimages of History. Critical Inquiry, 24(3), 666-699.

Publisher's Note Springer Nature remains neutral with regard to jurisdictional claims in published maps and institutional affiliations.

\section{Authors and Affiliations}

\section{Mateusz Świetlicki ${ }^{1}\left[\right.$ (Dorota Michułka ${ }^{2}$}

$\square$ Mateusz Świetlicki

mateusz.swietlicki@uwr.edu.pl

Dorota Michułka

dorota.michulka@uwr.edu.pl

1 Institute of English Studies (University of Wrocław, Poland), ul. Kuźnicza 22, 50-138 Wrocław, Poland

2 Institute of Polish Studies (University of Wrocław, Poland), plac Nankiera 15b, 50-140 Wrocław, Poland 